\title{
Phantasmagorical Buddhism: Dreams and Imagination in the Creation of Burmese Sacred Space
}

\author{
Thomas Nathan Patton $(\mathbb{D}$ \\ Department of Asian and International Studies, City University of Hong Kong, Kowloon Tong, Hong Kong; \\ tpatton@cityu.edu.hk
}

Received: 17 November 2018; Accepted: 11 December 2018; Published: 13 December 2018

\begin{abstract}
Despite the growing research done on sacred spaces in Buddhist Myanmar, no attention has yet been given to the role dreams play in the selection and development of such spaces. This article will address this lacuna by exploring how dreams are regarded by 20th-21st centuries Buddhists in Myanmar, as evidenced in autobiographies, ethnographic work, and popular literature in relation to the creation and evolution of sacred places. Although there are many kinds of sacred sites in Myanmar, this article will look specifically at Buddhist stupas, commonly referred to in Burmese as, pagoda or zedi. These pagodas, found in nearly every part of Buddhist Myanmar, are also those structures most prevalent in Buddhist dream accounts and often take on phantasmagorical qualities when those same Buddhists attempt to recreate the pagodas of their dreams.
\end{abstract}

Keywords: Theravada; Buddhism; sacred space; dreams; material religion; Myanmar; Burma; pagoda; wizard; weizzā/weikza

\section{Sacred Places in Buddhist Myanmar}

According to orthodox Theravada Buddhist teachings, the Buddha is considered dead and the canon of Buddhist scriptures closed. Despite this, revelations attributed to the Buddha's disciples are still ongoing, especially for those Buddhists who experience dreams of particular Buddhist entities appearing to them to impart new knowledge in the form of prophecies or directives. Such Buddhists have ongoing extraordinary experiences that I refer to as phantasmagorical: sequences of imaginary images, as seen in a dream, of Buddhist supernatural agents appearing to them to convey meditation practices, magical spells, iconography, and, instructions for creating sacred spaces. This article focuses specifically on the relationship between dreams and sacred sites. Examining Burmese Buddhists' dream and visionary experiences, the article shows how both the felt anomalous nature of such experiences and the attribution processes through which these experiences are considered special are shaped into religious ideas and places of great potency in contemporary Myanmar. The reverse is also true. The attribution processes are determined by the religious ideas and the knowledge of places of great potency.

Buddhist sacred places in Myanmar are legion, seemingly appearing wherever one looks. Small street side shrines, impressive mountaintop pagodas, ornate cave temples, and non-descript village statues are just some of the various kinds of sacred places one can find. Some, like the Shwedagon Pagoda in Yangon have survived the passage of time, growing in power and glory in the hearts and minds of the thousands of Buddhists that visit every day. Other sacred sites, however, fall into disrepair when Buddhists, for whatever reason, find such places no longer efficacious or auspicious. Regardless of the sites' popularity at any given moment, each place came into being as a result of a particular event. Most sacred sites in Myanmar evolved as a result of specific myths and legends that acted as the impetus for a site to be developed (Stadtner 2015) while others were given sacred status as a result of some natural or supernatural occurrence attached to the site or when 
religious artifacts were discovered at those spots (Stadtner 2015, 2008; Moore 2007, p. 24). Still others have become sacred because they are believed to be linked with treasure troves guarded over by protective spirits (Foxeus 2017; Mahāsaddhammajotikadhaja 2006, pp. 273-77). In Burmese language sources, both written and oral, a significant proportion of these sacred sites arise from dreams. Despite the growing research on sacred Buddhist spaces in Myanmar, no scholarship on the role of dreams in the development of sacred space has yet been carried out. This article, therefore, is interested in how dreams help determine how particular sites are developed and designated as sacred, as well as how the religious structures erected on such sites perform specific sacred functions. Before turning to such a discussion, however, we must first explore the role dreams play in the lives on Burmese Buddhists.

\section{Dreams in Burmese Buddhism}

In his wide-ranging book, Dreaming in the World's Religions: A Comparative History, Kelly Bulkeley asserts that "[i]n terms of function, Buddhism regards ordinary dreaming as a distracting nuisance, although most Buddhists will grudgingly acknowledge a prophetic power in certain dreams" and that "[i]n Buddhism, the question of how to interpret dreams is answered not by a waking analysis of the dream's contents but by an enlightened awareness within the dream of its illusory nature" (Bulkeley 2008, pp. 108-9). Other scholars working on dreams and religion, like the philosopher, Thorsten Botz-Bornstein, declares that "Buddhism is not interested in imagination but in reality" (Botz-Bornstein 2007, p. 72). Aside from the issue that Bulkeley and Botz-Bornstein make no effort to qualify what they mean when they use the term, "Buddhism," their notions that Buddhists themselves do not take dreams seriously, have a negative view of dreams, or only examine them in the context of meditation or spiritual progress is wrong. For this article, I will pay close attention to the prominent roles dreams play in the lives of Burmese Buddhists. Such Buddhists have ongoing phantasmagorical experiences: sequences of imaginary images, like that seen in a dream, of supernatural agents appearing to them to convey new Buddhist teachings, bestow magical spells, unlock supernatural powers, issue warnings, or foretell futures. These imaginaries are very real to the devotees experiencing them and not simply mental apparitions.

For Buddhists in Myanmar, rather than being sources of suspicion and disregard, dreams are fonts of visionary knowledge to be taken seriously and respected. They are foundations of omens and divine revelations and are part of a suprasensible world that has an ontological status, one that is as real as the one they perceive with their senses. There are scores of popular Burmese language books on dreams that can be found in any book store in Myanmar, as well as a growing number of Facebook groups and websites devoted to dream sharing and interpretation within Burmese contexts. Visiting online Burmese bookshops, for instance, one finds over one-hundred books related to dreams. Having read a bulk of such literature, I learned that the context of these sources supports the notion that "dreams count for as much as wakeful perception ... While experience [in both dreams and wakeful perception] are both subject to the same categorizations; both, for example, can have the character of "present reality'" (Littlejohn (1960, p. 71) quoted in Shaw (1992, p. 36)). Monks, hermits, and other kinds of Buddhist saints appear in dreams to grant supernatural powers, offer life-altering information, and provide cures for various diseases. The dreamer uncovering lost items, hearing voices on how to make someone fall in love with the dreamer or being given winning lottery numbers are also prevalent themes in written and oral accounts. For the most part, dreams are considered self-explanatory and thus not needing the aid of further interpretation. However, for those dreams that beg to be interpreted due to their lack of clarity, professional and amateur dream interpreters that set up shop on the premises of popular Buddhist sites, dream manuals, or Facebook groups on Buddhist dream discussions are readily available.

Burmese Buddhists understand their worlds to be governed by two distinct, and at times overlapping, bases of knowledge. The first set, referred to as "this-worldly" (lokiya) knowledge/arts consists of five branches: (1) dreams, omens, and predictions; (2) sacred diagrams, amulets, and verses; 
(3) astrology and palmistry; (4) alchemy; and (5) indigenous medicine. ${ }^{1}$ Knowledge gained from these five branches can be used to manipulate the world for mundane ends. At the other end of the spectrum is "other-worldly" (lokuttara) knowledge and refers to specialized knowledge gained from meditation or scriptural study that is used for attaining Nirvana. There are many Burmese language sources comprising of books, monthly journals, websites, and Facebook groups that offer detailed explanations for each of the five branches of "this-worldly knowledge", as well as those pertaining to "other-worldly knowledge" - a large portion of which are dedicated to the interpretation of dreams. The popular Buddhist lokiya and lokuttara magazines in publication from the 1990s to the present consistently include articles and interviews about dreams. ${ }^{2}$ The detail with which these dreams are recorded offer valuable insight into the reoccurring themes and elements considered important by Burmese Buddhists of a wide spectrum of socio-economic backgrounds. One gleans from these sources that dreams are more than just visions created by the mind during sleep. They are windows into the Burmese Buddhist world where people have ways of communicating with supernatural Buddhist agents that are otherwise not readily available during their waking states. These supernatural agents "have full access to information of strategic importance to humans. The relevance of dreams often relates to the dreamers' concerns about the future and about health" (Nordin 2011, p. 225). There are aspects about the dream state that they believe to be just as real as what they would experience in their waking states and are understood as directly influencing, in tangible ways, one's experiences with the waking world. As we will see below, such dreams are often of specific places in Myanmar; places where miraculous and insightful things occur.

Although the content of such dreams and their interpretations fill the pages of popular magazines, there are no sophisticated sources of Buddhist dream literature (oneirocritical works) that one finds in other religious traditions, certainly not as sophisticated as what one finds in Islam, for example. As Jamal Elias shows in the context of Islam, dreams and the systematic collection and interpretation of dreams formed the basis for an oneirocritical tradition to develop and maintain a prominent position throughout the history of Islam (Elias 2012, p. 203). Accepted as authentic sources of knowledge, dreams, and their connections to revelation and religious authority, were clearly defined in hadith literature (Elias 2012, p. 203). Because no such authoritative sources exist for dreams involving Buddhists, devotees rely on an informal oral tradition of dream interpretation in unpublished manuals, articles in popular religious magazines, books on visions and prophecies, and a host of professional dream interpreters and fortune tellers gathered around religious sites. However, as in Islam, dreams in the Burmese Buddhist tradition remain important sources of revelation and moral lessons, and a "broader, less easily defined variety of literature in which dreams serve a variety of functions including conferring status, providing evidence, and symbolizing interpersonal relationships" (Elias 2012, p. 200).

Dreams are the primary means by which the majority of Burmese Buddhists experience supernatural agents coming into their lives. These experiences are completely passive in that, although people can engage in preliminary religious rituals and exercises to increase the chances that a supernatural agent will visit them during their sleep, they are mostly at the mercy of the agent as to when and how such a visitation may occur. ${ }^{3}$ For those whose first contact with a Buddhist entity is made during a dream, they frequently cite that initial experience as the most formative and influential in the bond that developed with the world of Buddhist saints and other deities. Dreams offer glimpses of devotees' connections to certain agents, which is important for providing confidence in their roles as followers or guardians of the Buddha's teachings. These are the kinds of dreams that are often referred

1 For more on each of these five branches, see, respectively: (Tosa 2005; Patton 2012; Htin Aung 1959; Rozenberg 2010; Coderey 2014).

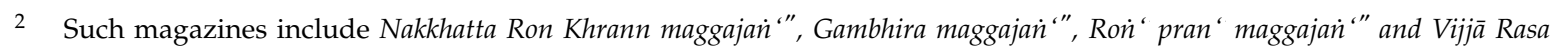
Con 'maggajan'".

3 Such rituals and exercises may include meditation, chanting sacred verses (mantra), smoking cigarettes, or chewing tobacco leaves. 
to whenever Buddhists share stories with one another. They also appear in devotional literature about how initial contacts with these agents impacted the ways they saw the world around them and the spirit entities that inhabited it.

Reading through hundreds of Burmese dream books, popular magazine articles and online dream sources over recent years, coupled with data collected from ethnographic work undertaken in the cities of Mandalay and Yangon and their surrounding towns and villages with interlocutors that included monastics and lay people, I have identified dreams as fitting into one of two broad, and at times, overlapping, categories: portentous dreams and didactic dreams. ${ }^{4}$ Dreams in the first category are ominous and prophetic, alerting the dreamer to something that will, or may, occur in his/her life. The second category deals with dreams that are revelatory and instructive, offering new teachings, insights, or practices related to both lokiya and lokuttara phenomena. In both cases, they are windows into the suprasensible world where the dreamer can witness unseen forces at work in his/her life and in those around him/her. Buddhist holy men dressed in the red robes of a monk, brown robes and beard of a hermit, or white robes and turban of a bodaw (a class of Burmese renunciants associated with lokiya practices and beliefs) appear in dreams acting as catalysts for the dreamer to engage in a life-changing act upon waking. Not unlike the Spirit of Christmas Yet-to-Come who shows Ebenezer Scrooge what may befall him if he does not change his ways, these Buddhist spirits appear bearing important, life-altering messages (see Figures 1 and 2).

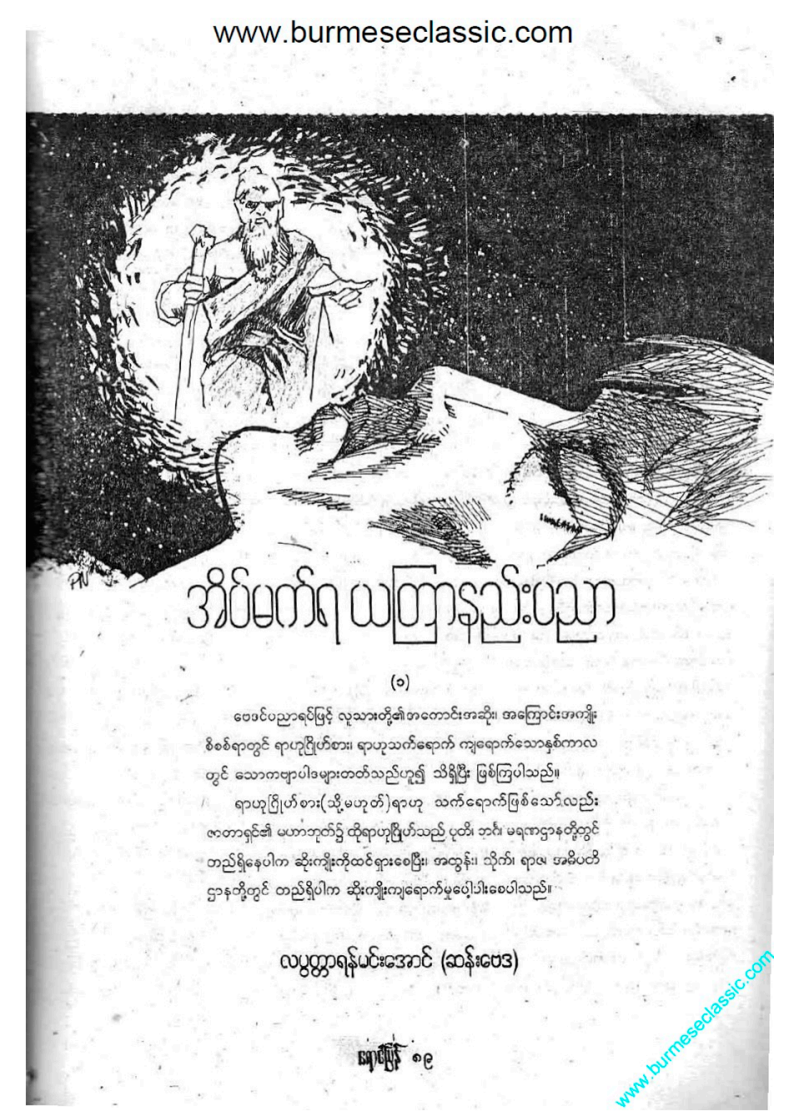

Figure 1. An example of dream accounts published in popular Burmese Buddhist magazines. Notice the counting beads around the necks of the hermits here and in Figure 2. (Ron' pran' maggajan'"l May 2015).

4 The conclusions from this research may not apply to all regions of Myanmar, therefore. 


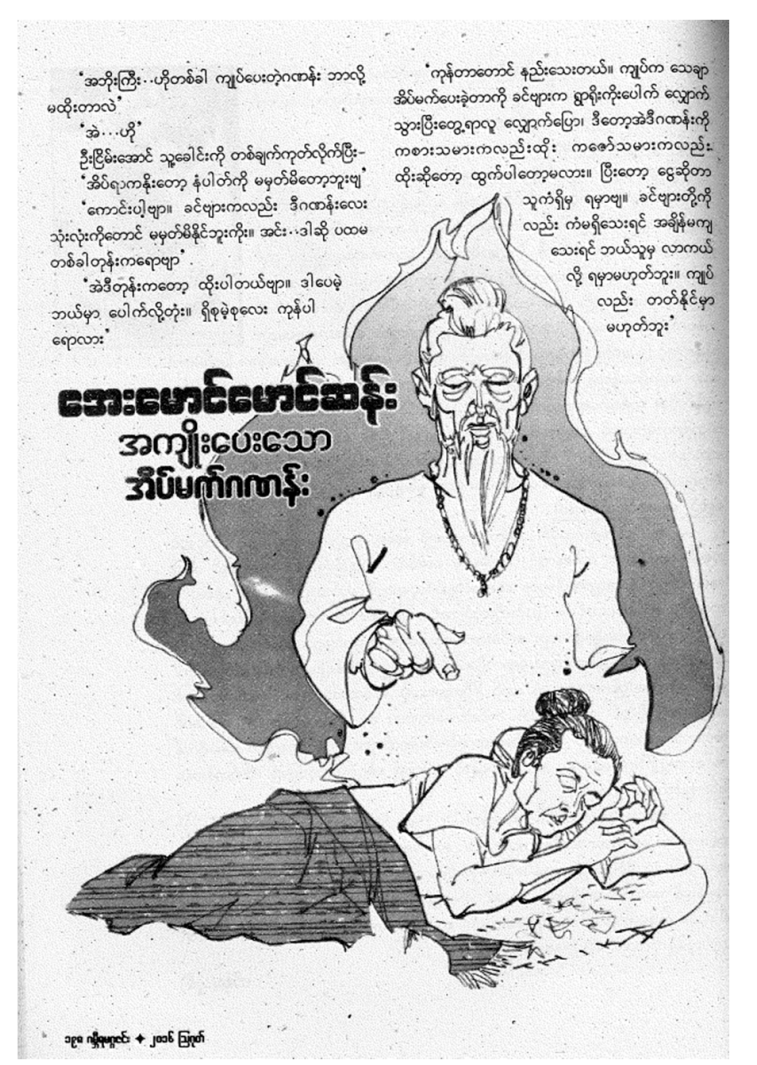

Figure 2. Another example of a dream account published in a popular Burmese Buddhist magazine.

(Gambhira maggajan' 'l August 2016).

Let us look first at the portentous type of dream, and in particular, how it often leads to the establishment of sacred sites. There is the account from one woman who, in a popular Buddhist magazine, recalls how she used to work as fishmonger, and that one night she had a dream where a man "bearded with long sideburns, like an Indian—as well as an old hermit—appeared and carried me off to hell. When I saw all the beings suffering in hell, I became very scared and asked [the two men] to bring me back home. They told me that if I continued to sell fish for a living that I would end up in hell after I died. Suddenly, a light atop a hill was calling out to me. When I followed it and arrived at the top of the hill, the pagodas and rest houses made me feel so peaceful." The dream had such a profound impact on her that very soon after, she left her job as a fishmonger and became a hermit dedicating her life to perfecting the "this-worldly" arts for the benefit of others and the Buddhist religion (NYK no. 116, 1996, pp. 34-37). This site has since become a major pilgrimage spot thanks, in large part to this woman's dream shared through popular media of magazines and Facebook posts.

Another sacred site in Myanmar that owes its development to this type of portentous dream is the fantastical Mei Lamu Pagoda in Yangon. Sometime in the late 1950s, Saw Nyunt Yi, wife of a local agricultural minister, dreamt of a dilapidated pagoda located somewhere on the outskirts of Yangon. One day while taking a train to the northern parts of Yangon, she was astonished to stumble upon the exact pagoda she has seen in her dream. Soon thereafter, in 1960, she applied for, and was given, a permit from the Department of Religious Affairs to renovate the pagoda (Mahāsaddhammajotikadhaja 2006, pp. 10-15). The pagoda complex has since become quite the attraction, drawing large numbers of locals and foreigners alike who come to see its "Disneyland-esque" dioramas, shop at any number of pop-up kiosks selling souvenirs, or walk through a giant crocodile statue that houses a museum in its belly and pagoda on its back (Stadtner 2015, p. 50; Patton 2017, p. 2).

Turning now to the category of dreams that are revelatory, we see some of the same themes appear here as in dreams of portentousness, especially with regards to the types of supernatural agents that appear and ways of interacting with the dreamer, the supernatural powers often gained as byproducts 
of such dreams, and a pre-occupation with lokiya aspects of one's life. What separates these dreams from the previous category, however, is their focus on offering the dreamer new ways of engaging or creating sacred spaces. For instance, of the hundreds of dream reports I have read and recorded, practices related to counting prayer beads at specific "places of power" (dhat pannek) features most prominently. Buddhists dream of monks, white-clad religious mendicants (bodaw) or wizard-saints (weizzā) appearing to them providing new methods for using counting beads, for instance. These counting beads, similar to Roman Catholic Rosary beads, consist of beads used to count component Buddhist verses. Unlike the Roman Catholic tradition that prescribes a basic structure and some variations and accepted additions, there are practically limitless possibilities when using Burmese Buddhist counting beads. Using counting beads for prolonged periods of time, with particular Buddhist verses in specific combinations and permutations, and that are composed of certain metal or wooden materials, are thought to bring to the user a variety of benefits ranging from increased concentration in meditation to obtaining benefits in both mundane and supramundane affairs. Verses and their corresponding variations, coupled with the beads' composite physical qualities and makeup, that are provided by religious agents and learned in a dream state are believed by Buddhists to be of special potency. It is not necessarily that they are more powerful than those derived from non-dream states, but rather, due to their originating from entities that are believed to access a font of knowledge that stretches beyond the human realm and into other suprahuman dimensions, offer Buddhists alternative means for getting what they want. One female hermit, known for her dedication to engaging in practices at a particular sacred site related to counting beads and who is believed to have supramundane powers, was interviewed in a magazine.

Interviewer: "Please tell us how you came about to be clairvoyant."

Hermit: "I've been blind since I was three years old. Around fifteen years of age, my grandfather appeared to me in a dream. He said that he was counting prayer beads at a pagoda in a certain city. He ordered me to do the same counting-bead method at a specific pagoda, which I did for forty-five days."

I: "What was so special about this counting-bead method?"

$\mathrm{H}$ : "Well, one day while saying my beads, I heard a loud voice at around seven o'clock in the morning. I asked out loud who whose voice this was. [A man's voice] replied. "I am seventy years old. I have come to offer you some wisdom."

I: "What did he bestow upon you?"

H: "He taught me how to save people. I have been clairvoyant for thirty years now. I meet with whoever comes to me. With regards to my clairvoyance, whatever I hear in my ear comes true and likewise with what I see."

I: "Please give us an example."

H: "In my home, when something happens that I fear may cause a fire, I can 'see' a burst of flames. Sometimes, too, I hear a voice say, 'What will happen?'"

I: "Have you ever seen anyone who supposedly comes and tells you things?"

H: "Yes, Sometimes I see a white robed person (bodaw) holding counting beads standing in front of a pagoda." (NYK no. 135, 1997, pp. 199-200)

Specific details of these counting-bead methods (much too detailed and lengthy to address here) and the sacred places in which they are to be done are provided in the hundreds of similar kinds of interviews and dream accounts. However, the material properties of these counting beads can often be considered just as, if not more, important than the techniques for using them. One elderly man recounts that when he was about forty years old, he dreamt of a bodaw unveiling to him a tree with powerful medicinal properties (NYK no. 171, 2000, pp. 30-31). The bodaw called over a jungle spirit (nat) and after receiving the tree from the spirit, cut off a piece and gave it to the dreamer. This piece 
suddenly became two trees, and the dreamer knew that it was a sign that this special tree should be distributed to others. Upon waking and reflecting on the dream, the man realized that the tree in his dream was identical to a tree in Myanmar used during certain religious festivals and is known for its medicinal properties. ${ }^{5}$ He took this dream to be a sign that he should create a set of counting beads made from the wood of this tree. Doing so, he found that using these beads had a profound effect on his meditation practice, allowing him to attain concentration much quicker than with beads made from other materials. He also experiences Buddha statues from popular religious sites around Myanmar appearing to him in his mind whenever he used these beads, and occasionally can see the fates of certain people play out before him.

\section{Imagination Bringing Phantasmagoria to Life}

What accounts for some dreams to be remembered, shared, and incorporated into normative religious expressions? What criteria do dreamers in Myanmar choose to examine some experiences and not others? How do they decide which dreams are worth examining? Drawing upon Ann Taves' theoretical work on anomalous experiences, I note that those dream experiences that Buddhists themselves consider anomalous and are worth taking note of. The Burmese words that Buddhists use to describe the emotionally charged experiences that arise from their dreams experiences with supernatural agents can be translated into English as "unusual" (htu kya), "strange" (san kyay), and "amazing" (an aw) and that these dreams often lead to gaining supernatural powers. Likewise, Ann Taves' recent work on religious studies theory reframes religious experiences as those that people deem "anomalous," "strange," or "special" and which are often associated with "non-ordinary powers." Some dream experiences and the resulting sensations, feelings, and emotions that arise from such dreams are more important than others and are what Buddhists share with one another in person, on internet websites, and through the pages of monthly magazines. The importance lies in their anomalies, or "things that people consider special because they are strange or unusual or in some way violate people's ordinary expectations" (Taves 2012, p. 72). Applying Taves' theory to dreams, this research explores both the felt anomalous nature of such experiences and on the attribution processes through which these experiences are considered special. In some cases, they are shaped into religious ideas and stable teachings and institutions in contemporary Myanmar. In addition to the emotionally charged, and oftentimes surreal abnormality, a dream's counterintuitivity also plays a role in the degree to which a dream is recalled and dispersed. Anthropologist Andreas Nordin posits that such dreams are relegated high status because they involve processing that is contrary to intuition or common-sensical expectations. This also suggests that "... counterintuition, besides bringing strong and vivid emotions, improves memorability, salience and the inferential potential of religious dreams, rendering these representations successful in cultural transmission and selection" (Nordin 2011, p. 236).

True, not all dreams that are shared are counterintuitive, and there are many counterintuitive dreams that are not considered special enough to share. Rather, it is the inclusion of a supernatural agent that lends such dreams to be recalled and narrated in the Burmese Buddhist cultural environment. These agents take the form of religious mendicants wielding supernormal powers that, although exceedingly rare, are considered by Burmese Buddhists to be byproducts of having advanced along the Buddhist path to enlightenment. Therefore, the agents' counterintuitivity "conform[s] to some intuitive ontologies while breaching others" (Nordin 2011, p. 228). As such, this genre of dreams, by virtue of their salience, are circulated through networks of family and friends as well as through a wide range of popular media. They are set and perpetuated as a Burmese culture's "cultural repertoire," informing the way a dreamer interprets, recounts, and manipulates the events they take part in in creating, as well as shaping the way new information is processed and articulated (McDaniel 2011, pp. 104-5; Patton 2016a).

5 The tree in question is the kyek-yone (Jasminum sambac) tree and is used especially during religious festivals. 
These dreams are what I have come to refer to as "phantasmagorical." Motivated by their dreams, many Burmese Buddhists attempt to physically materialize their dream experiences in their everyday, non-sleeping worlds. One main avenue for how they accomplish this is through constructing religious structures that deviate quite radically from the more traditional ones found ubiquitously spread throughout Myanmar. ${ }^{6}$ Using a standard definition of phantasmagoria as a fantastical combination, collection, or assemblage of images, such edifices are certainly phantasmagorical in nature, exactly because these structures are inspired by counterintuitive, supernatural agent-laden dreams. Not simply content to model their structures on inspiration gained from these dreamers, some Buddhist architects are determined to replicate, as closely as possible, what they witness in their dreams.

The Thambuddhe and Arlein Nga Sint pagoda complexes in Monywa and Yangon, Myanmar, respectively, are two examples of such sites. Both were built around the mid-20th century in accordance with designs taken directly from the dreams of monks. Monhyin Sayadaw, the monk who initiated construction of the Thambuddhe Pagoda complex, experienced dreams of supernatural agents in the form of hermits, bodaw and wizard-saints dictating the layout of the religious edifices. Likewise, the monk and architect of the Arlein Nga Sint Pagoda had similar dreams of Buddhist agents appearing to him providing details for where and how to construct the pagoda (see Figure 3). These monk architects considered their dreams to be the blueprints for their construction projects and attempted to replicate what they experienced in their dreams. This included not only the architectural proportions, but affective dimensions as well.

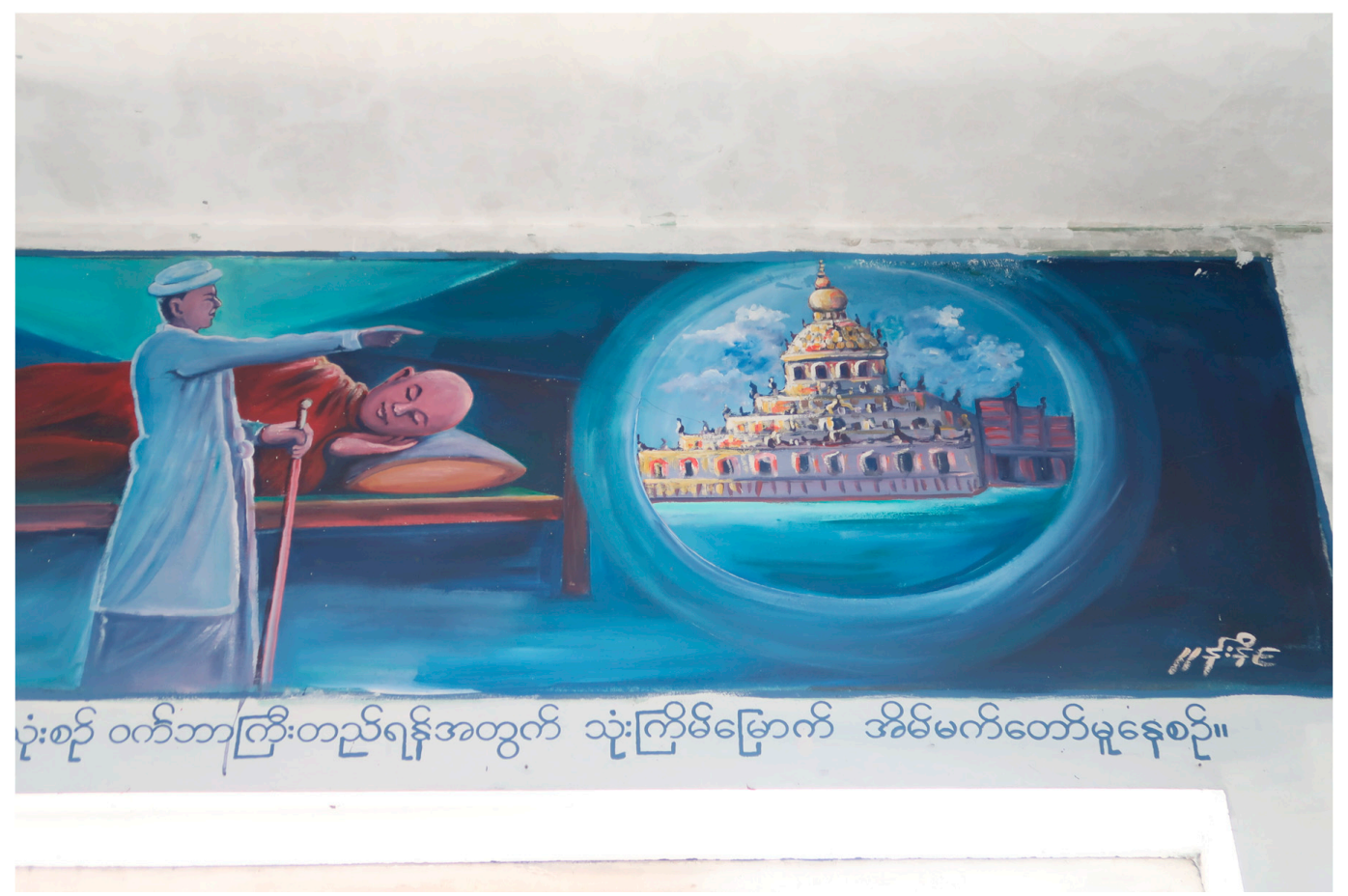

Figure 3. A painting located at the Arlein Nga Sint Pagoda in Yangon depicting the architect monk dreaming of a bodaw telling him what kind of pagoda to construct.

These Buddhist architects wanted the structures to evoke similar emotions, thoughts, feelings, in people who visited their edifices as they experienced in their dreams. Heavenly fruits, fantastical creatures, high ceilings with European styled chandeliers, mirrors lining all corners of the large structures, thousands upon thousands of Buddha statues and sacred diagrams adorning the walls 
and lavishly painted in bright colors of yellows, reds, and blues they are sites that, as Justin McDaniel points out, work "on the visitor and in total possesses an affective potential" (McDaniel 2016, p. 23). In this sense, such sites are phantasmagorical exactly because spectators are often reduced "to an attitude of pure reaction" and give its visitors a "frame for immediate enjoyment" (Berdet 2013). Such places "do not teach through narrative," McDaniel writes, "but by immediacy. They keep a person in the moment of aesthetic enjoyment" (McDaniel 2016, p. 24). The Arlein Nga Sint Pagoda, for instance, is a uniquely baroque multi-tiered structure coated with nearly two-hundred kilograms of gold. The vaulting upper section appears more French château than Theravada temple, with powder blue walls and lavish Rococo windows and moldings (see Figures 4-6). The pagoda is surrounded by a low-walled labyrinth that, when not locked behind a gate, allows visitors to casually meander through the complex maze-like structure.

Perhaps more important than aesthetic enjoyment, however, is how these sites function as places of protection for Buddhists in general, and the country of Myanmar, in particular. Most of the dream-inspired building projects are of pagodas whose origins are a mix of phantasm, portentousness, and protection. Daw May, a senior member of the Ministry of Health, admitted to me one afternoon after locking her office door. Wealthy and well-educated, Daw May said that she was never very interested in religious activities until one night she had a dream where she "I saw a large man, who looked like [a wizard], riding a horse on a cold, misty morning," recounted Daw May. She could not make out the details of the man's appearance because of the fog, but the rider told her "that the next few years will be filled with natural and political catastrophes all around the world" and that she must erect a specific kind of pagoda in order to keep such catastrophes from taking place in Myanmar. She did not attach any importance to the dream until several years later when, in 1994, she had a similar dram while she was engaged in work along the Myanmar-Thai border. "[The wizard] told me to erect a pagoda in this area using donations from Shan and Thai people and make sure to invite them to the pagoda finial topping ceremony," Daw May continued. "He even gave me a vision of what the pagoda should look like." As she explained further, she could no longer ignore these dreams and took them as a sign that the wizard had chosen her to carry out religious activities for the protection and stability of her country.

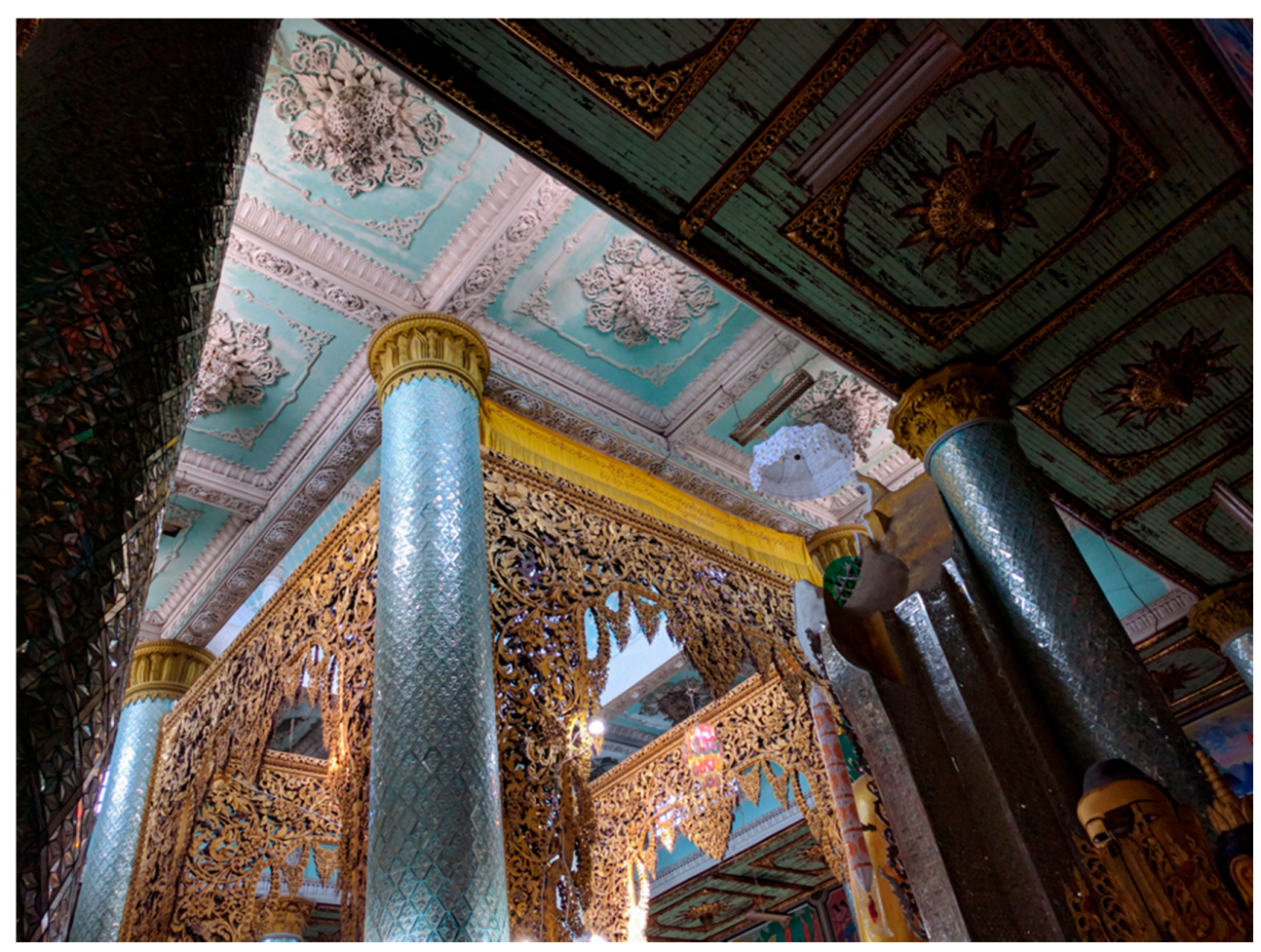

Figure 4. Photograph of the inside of the Arlein Nga Sint Pagoda. 


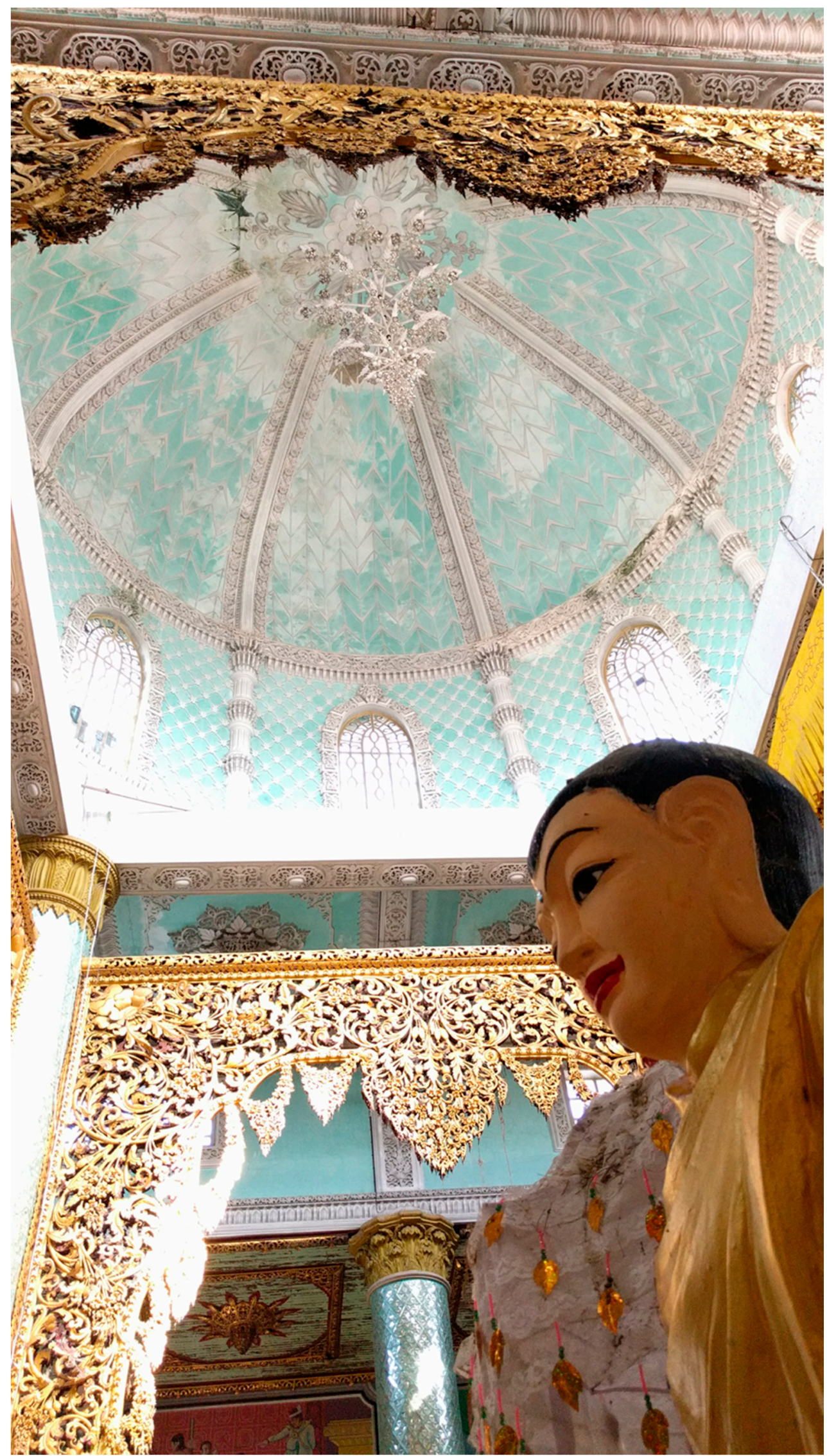

Figure 5. Photograph of the inside of the Arlein Nga Sint Pagoda. 


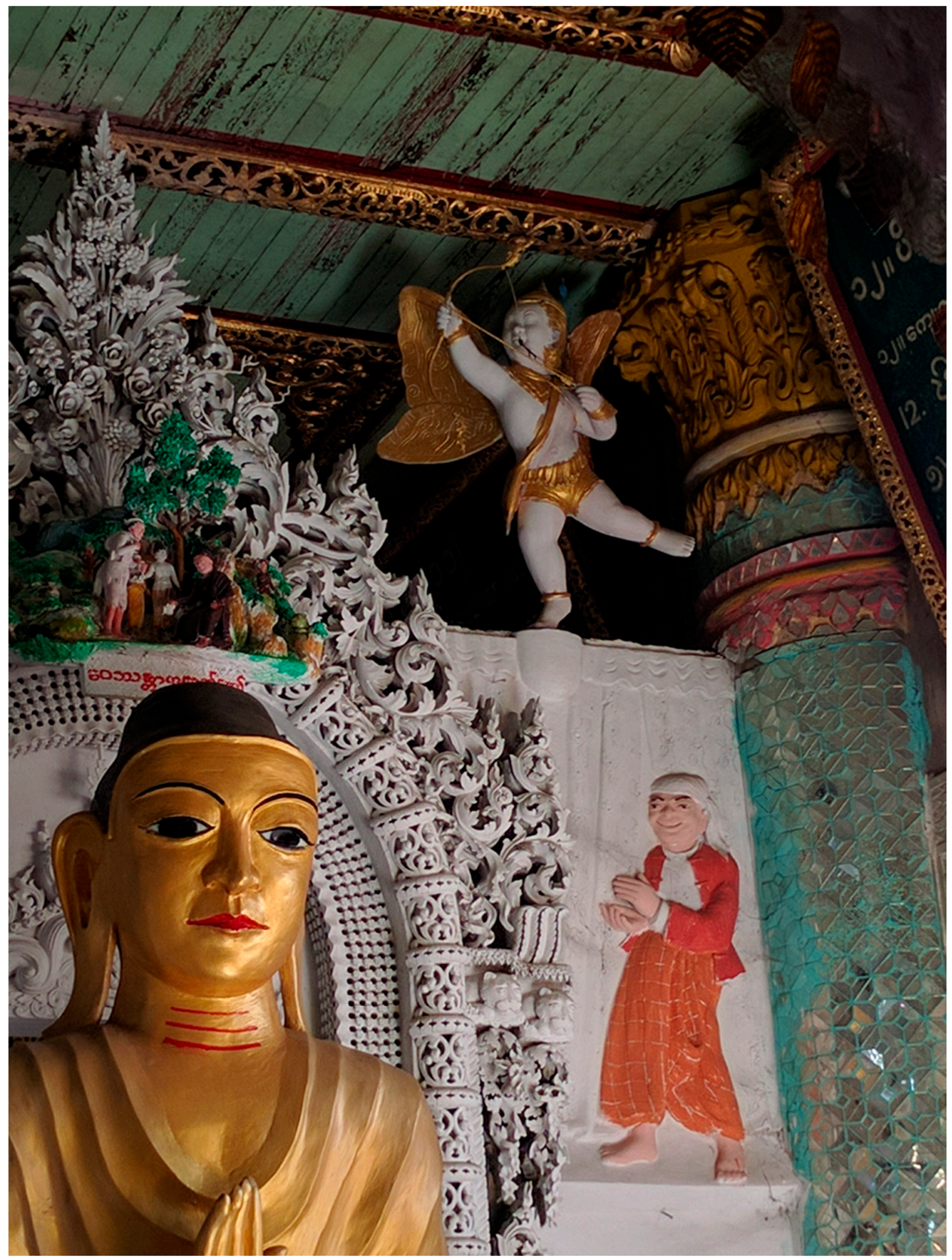

Figure 6. Photograph of the inside of the Arlein Nga Sint Pagoda.

Such a dream, and the subsequent construction of a pagoda inspired by that dream, is a common theme found in many dream accounts: Having prescience that a catastrophe will soon befall the country and its Buddhist population, a Buddhist entity appears to the dreamer entreating him/her to build a pagoda that has apotropaic properties to keep the prophesized dangers at bay 
(Patton 2018, 2016b). Precedents for which can be traced back to at least the anti-Colonial movements of the 1930s (The Rebellion in Burma, April 1931-March 1932, Confidential, para. 8, L/P\&J/6/2020). The pagodas in question are quite unlike the more traditional ones found ubiquitously spread throughout Myanmar. As anyone who has spent time in the country or looked through picture books on pagodas knows that the typical pagoda style, like the bell-shaped Shwedagon, is one with only slight stylistic variations between pagodas of this kind. Pagodas that trace their provenance to directives provided by Buddhist entities in dreams, however, deviate substantially in that they exhibit variations in shapes and configurations seldom found in more traditional pagodas. ${ }^{7}$ Indeed, this is exactly what we find in the Thambuddhe Pagoda discussed above (see Figure 7). Built at the start of the Second World War, the pagoda, whose official name is "The Pagoda That Overcomes the Three Catastrophes" (thambuddhe kap-kyaw zedi) was erected with the belief that it would protect the country from, disease, famine, and war (Sumana 1990, pp. 207-9).

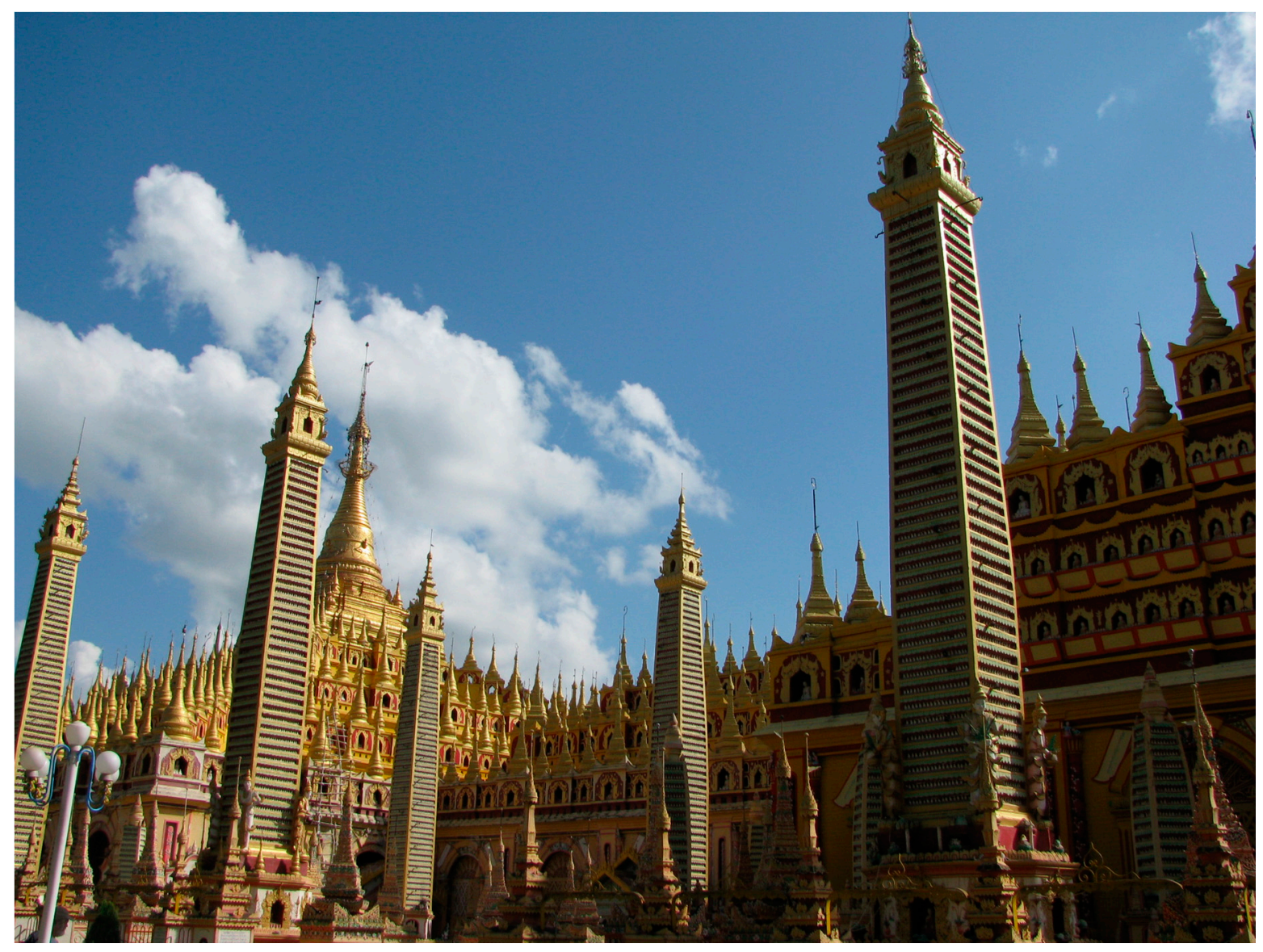

Figure 7. Thambuddhe Pagoda in Monywa, Myanmar. Photo courtesy Andrew Dicks.

\section{Conclusions}

Rather than downplaying the role of dreams in the histories and lived experiences of Buddhists and the places they deem sacred, this article has shown that dreams are accorded important status in the Burmese Buddhist tradition of determining the sacredness of specific places in Myanmar. Buddhists identify, ruminate upon, and share those dreams that are special, i.e., contain supernatural agents of a counterintuitive nature bearing messages that have the potential of transforming the lives of the dreamer in both mundane (lokiya) and supramundane (lokuttara) affairs. The religious worlds that

7 Tosa (2012) refers to such dream inspired structures as "non-standard religious buildings". 
Buddhists experience in their dreams and which are transferred to the waking world in the forms of phantasmagorical pagodas are intensely affective, especially when it pertains to the material and visual aspects of religion. Attending to such aspects conveys the "sensuous life of a religion, shaping, coloring, and organizing" that it often overlooked by scholars working on dreams in Buddhism. ${ }^{8}$

Funding: This research was funded, in part, by project No. 21608215 of the Hong Kong Research Grant Council and project No. 7200508 of the City University of Hong Kong.

Acknowledgments: I would like to thank John Nelson for guidance and feedback on early drafts of this article.

Conflicts of Interest: The author declares no conflict of interest.

\section{References}

Berdet, Marc. 2013. Eight Thesis on Phantasmagoria. Anthropology \& Materialism 1. [CrossRef]

Botz-Bornstein, Thorsten. 2007. Dreams in Buddhism and Western aesthetics: Some thoughts on play, style and space. Asian Philosophy 17: 65-81. [CrossRef]

Bulkeley, Kelly. 2008. Dreaming in the World's Religions: A Comparative History. New York: New York University Press.

Coderey, Céline. 2014. Healing through Weikza: Therapeutic Cults in the Arakanese Context. In Champions of Buddhism: Weikza Cults in Contemporary Burma. Edited by Bénédicte Brac de la Perrière, Guillaume Rozenberg and Alicia Turner. Singapore: NUS Press.

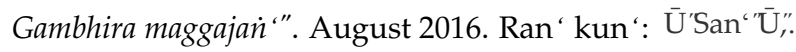

Elias, Jamal J. 2012. Aisha's Cushion: Religious Art, Perception, and Practice in Islam. Cambridge: Harvard University Press.

Foxeus, Niklas. 2017. Possessed for Success: Prosperity Buddhism and the Cult of the Guardians of the Treasure Trove in Upper Burma. Contemporary Buddhism 18: 108-39. [CrossRef]

Htin Aung, Maung. 1959. Folk Elements in Burmese Buddhism. Rangoon: Department of Religious Affairs.

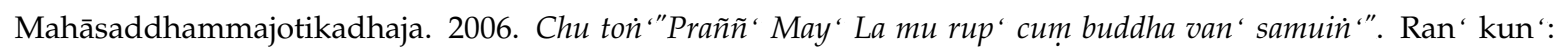
Kambha 'ae".

Littlejohn, James. 1960. The Temne House. Sierra Leone Studies n.s. 14: 63-79.

McDaniel, Justin. 2016. Architects of Buddhist Leisure: Socially Disengaged Buddhism in Asia's Museums, Monuments, and Amusement Parks. Honolulu: University of Hawai'i Press.

McDaniel, Justin. 2011. The Lovelorn Ghost and the Magical Monk: Practicing Buddhism in Modern Thailand. New York: Columbia University Press.

Moore, Elizabeth H. 2007. Early Landscapes of Myanmar. Bangkok: River Books.

Morgan, David. 2012. The Embodied Eye: Religious Visual Culture and the Social Life of Feeling. Berkeley: University of California Press.

Nordin, Andreas. 2011. Dreaming in religion and pilgrimage: cognitive, evolutionary and cultural perspectives. Religion 41: 225-49. [CrossRef]

Patton, Thomas. 2018. The Buddha's Wizards: Magic, Power and Healing in Burmese Buddhism. New York: Columbia University Press.

Patton, Thomas. 2017. Buddhist Wonderlands: Thoughts on Architects of Buddhist Leisure. Heidelberg Ethnology 5: 2-4.

Patton, Thomas. 2016a. The Wizard King's Granddaughters: Burmese Buddhist Female Mediums, Healers, and Dreamers. Journal of the American Academy of Religion 84: 430-65. [CrossRef]

Patton, Thomas. 2016b. Buddhist Salvation Armies as Vanguards of the Sāsana: Sorcerer Societies of Burma's Liberation Era. Journal of Asian Studies 75: 1083-104. [CrossRef]

Patton, Thomas. 2012. In Pursuit of the Sorcerer's Power: Sacred Diagrams as Technologies of Potency. Contemporary Buddhism 13: 213-31. [CrossRef]

Ron' pran' maggajañ'". 2015. Ran 'kun' Mrui': Mon' Mon' Mran “"E,".

8 (Morgan 2012, p. 147). 
Rozenberg, Guillaume. 2010. “The Alchemist and His Ball” (translated from the French by Ward Keeler). The Journal of Burma Studies 14: 187-228. [CrossRef] [PubMed]

Shaw, Rosalind. 1992. Dreaming as Accomplishment: Power, the Individual and Temne Divination. In Dreaming, Religion, and Society in Africa. Edited by M. Charles Jedrej and Rosalind Shaw. Leiden: E.J. Brill.

Stadtner, Donald Martin. 2015. Sacred Sites of Burma: Myth and Folklore in an Evolving Spiritual Realm. Bangkok: River Books.

Stadtner, Donald Martin. 2008. Golden Rock. SOAS Bulletin of Burma Research 6.1-2: 19-69.

Sumana. 1990. Mui” ñ̃nhan’" Sambuddhe Cetiyakathā. Mre nai Kye” rvā, Mum rvā Mrui' nay ': Mui" ññhañ “" To ra Kyon “" Tuik'.

Taves, Ann. 2012. Special Things as Building Blocks of Religions. In The Cambridge Companion to Religious Studies. Edited by Robert Orsi. Cambridge and New York: Cambridge University Press.

Tosa, Keiko. 2012. From Bricks to Pagodas: Weikza and the Rituals of Pagoda-Building. Journal of Burma Studies 16: 309-40. [CrossRef]

Tosa, Keiko. 2005. The Chicken and the Scorpion: Rumor, Counternarratives, and the Political Uses of Buddhism. In Burma at the Turn of the Twenty-First Century. Edited by Monique Skidmore. Honolulu: University of Hawai'i Press.

(C) 2018 by the author. Licensee MDPI, Basel, Switzerland. This article is an open access article distributed under the terms and conditions of the Creative Commons Attribution (CC BY) license (http:/ / creativecommons.org/licenses/by/4.0/). 